\title{
First record of the crab Callinectes sapidus Rathbun, 1896 (Crustacea Decapoda Brachyura Portunidae) off Favignana (Sicily, Italy)
}

\author{
Gabriele Sercia' \& Gianna Innocenti² \\ ${ }^{1}$ Casamuseo "Matteo Sercia" Via Sebastiano Galigarsia, 91023 Favignana, Italy \\ ${ }^{2}$ Sistema Museale di Ateneo, Museo di Storia Naturale, Sede La Specola, via Romana 17, 50125 Firenze, Italy \\ *Corresponding author, e-mail: gianna.innocenti@unifi.it
}

\begin{abstract}
The record of the blue crab Callinectes sapidus Rathbun, 1896 (Crustacea Decapoda Brachyura Portunidae) off Favignana (Aegadian Islands, Sicily, Italy) at 60-70 m depth is reported. A possible hypothesis on the unusual depth of collection is given.
\end{abstract}

KEY WORDS Callinectes sapidus; Favignana; alien species; Mediterranean Sea.

Received 11.08.2020; accepted 08.10.2020; published online 22.11.2020

\section{INTRODUCTION}

The European Callinectes sapidus Rathbun, 1896 (Crustacea Decapoda Brachyura Portunidae), native to the North American Atlantic Ocean (Galil et al., 2002), has been introduced into the Mediterranean Sea probably through ballast waters (Holthuis \& Gottlieb, 1955) and it first colonized the eastern part (Galil, 2011). Afterwards, numerous papers reported its presence in several places in the Mediterranean Sea such as Turkey, Israel, Greece, Croatia, Algeria, Spain, and France, in coastal waters and from lagoons or estuaries (all the localities are resumed in Labrune et al., 2019).

In Italy, its first finding dates back to 1949 and 1951 in the Venice lagoon (Giordani Soika, 1951; Mizzan, 1993), then it has been reported in other Adriatic localities, from brackish and coastal waters (Mizzan, 1993; Scaravelli \& Mordenti, 2007; Florio et al., 2008; Giansante, 2012; Castriota et al., 2012, Mancinelli et al., 2013; Cilenti et al., 2015; Manfrin et al., 2016; Pagliara \& Mancinelli, 2018). Other specimens were collected from the Gulf of Genova
(Suaria et al., 2017), Tuscany (Bisconti \& Silvi, 2005), Sardinia (Piras et al., 2019; Culurgioni et al., 2020 ) and the Ionian Sea, in Apulia (Gennaio et al., 2006), Basilicata (Stasolla \& Innocenti, 2014) and Calabria (Sperone et al., 2015) regions. Cerri et al. (2020) resumed the finding of the blue crabs in Italy based on the observations of correspondents, but for Sicily, it was reported only off Palermo.

The species is euryhaline and in North America lives in estuaries and marine embayments from the water edge to approximately $90 \mathrm{~m}$ depth (mainly at depths $<35 \mathrm{~m}$ ) on muddy and sandy bottoms (Hill et al., 1989). It is worth mentioning that in the Mediterranean localities, C. sapidus are found in numbers in similar habitats, mainly in estuaries and lagoons, but not in high sea.

\section{MATERIAL AND METHODS}

The study area is placed in Favignana (Aegadian Islands, Sicily, Italy).

The sample was captured in gill and trammel 
nets, photographed, then frozen and preserved in $70 \%$ ethanol, and deposited in the Casamuseo "Matteo Sercia" in Favignana island (collection number CCGS 0037).

\section{RESULTS}

An adult male specimen of $C$. sapidus (carapace width $94.0 \mathrm{~mm}$, carapace length $50.2 \mathrm{~mm}$, wet weight $75 \mathrm{~g}$ ) was captured in gill and trammel nets (mesh $70 \mathrm{~mm}$ ), at south Favignana Islands, 700800 meters depth west Secca del Toro (Sicily, Italy), on 3 August 2020, at 60-70 meters depth, on a sandy-rocky bottom (Fig. 1).

For its identification, it has been compared to a male specimen (carapace width $156.0 \mathrm{~mm}$, carapace length $80.3 \mathrm{~mm}$; CCGS 0038) from Sottomarina beach, near Chioggia, Venice Lagoon, obtained and offered by M. El Assil in September 2020.

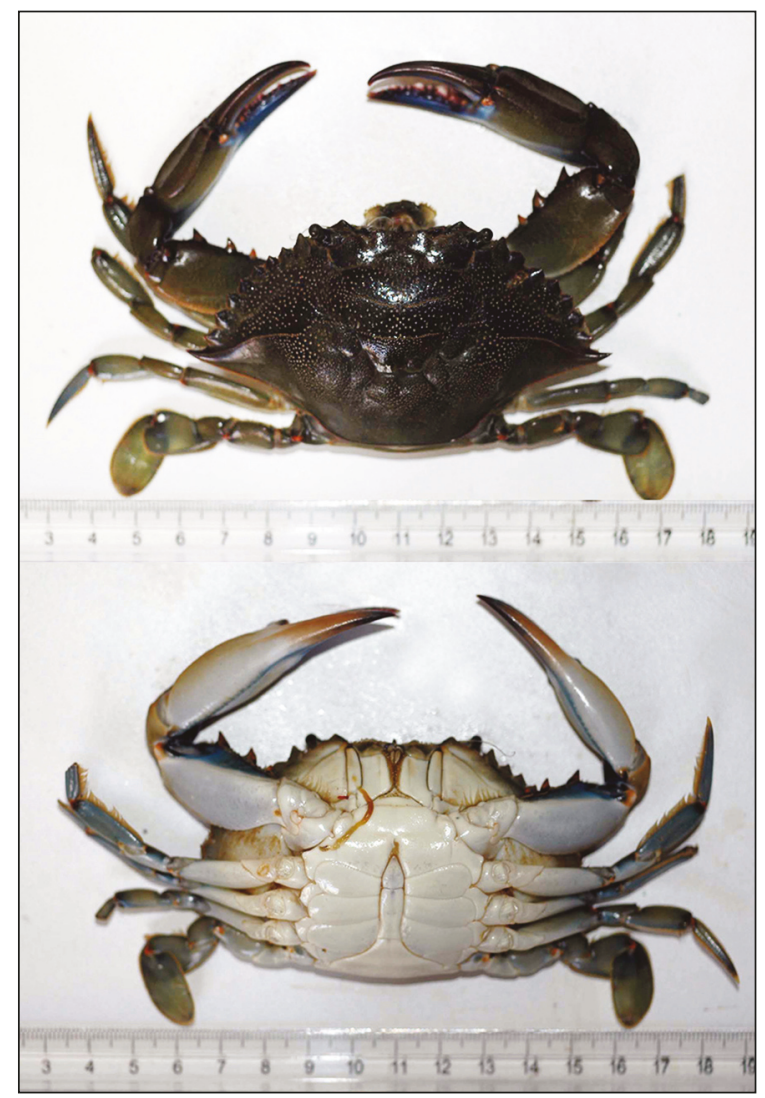

Figure 1. Callinectes sapidus, male, collected at south Favignana (Aegadian Islands, Sicily), 700-800 m west Secca del Toro, Sicily, Italy (CCGS 0037) (photo G. Sercia).

\section{DISCUSSION AND CONCLUSIONS}

The present record from Favignana island is not unexpected given the species' presence in southern Sicily (Stagnone di Marsala, Trapani: Comune di Marsala, 2015; Agrigento: Insacco \& Zava, 2017; Lampedusa Island: Cerri et al., 2020; Gulf of Castellammare, Palermo: Pipitone et al., 2020; Strait of Sicily: Falsone et al., 2020), however, the depth at which it has been caught is surprising, as it was fished in open sea.

The plausible hypothesis of this finding can be ascribed to the fact that anglers are fishing with crab traps Carcinus aestuarii Nardo, 1847 (Decapoda Portunidae) in the Stagnone di Marsala, where $C$. sapidus is commonly sharing the habitat with this autochthonous portunid crab (Comune di Marsala, 2015), and use them as baits for octopuses off Favignana (between 30 and $50 \mathrm{~m}$ depth) (Giacomo Campo, personal communication). Probably one specimen was among the $C$. aestuarii baits and escaped from the crab net, being, as a portunid, an excellent swimmer. In literature, only Daban et al. (2016) observed a single $C$. sapidus at $220 \mathrm{~m}$ depth from the North Aegean Sea, but any possible explanation of this finding was hypothesized.

\section{ACKNOWLEDGEMENTS}

We wish to thank Giacomo, Vincenzo and Giuseppe Campo (Favignana, Trapani, Italy) and Myriam El Assil (Venezia, Italy) for their help. Thanks are due to Gianluca Stasolla (Santeramo in Colle, Bari, Italy) and to Fabio Crocetta (Napoli, Italy) for comments on a preliminary draft.

\section{REFERENCES}

Bisconti M. \& Silvi E., 2005. Prima segnalazione di Callinectes sapidus Rathbun, 1896 (Crustacea, Decapoda, Brachyura) nella provincia di Livorno. Quaderni del Museo di Storia Naturale di Livorno, 18: 1-6.

Castriota L., Andaloro F., Costantini R. \& De Ascentiis A., 2012. First record of the Atlantic crab Callinectes sapidus Rathbun, 1896 (Crustacea: Brachyura: Portunidae) in Abruzzi waters, central Adriatic Sea. Acta Adriatica: international journal of Marine Sciences, 53: 467-470.

Cerri J., Chiesa S., Bolognini L., Mancinelli G., Gratic 
F., Dragičevićh B., Dulčich J. \& Azzurro E., 2020. Using online questionnaires to assess marine bio-invasions: A demonstration with recreational fishers and the Atlantic blue crab Callinectes sapidus (Rathbun, 1986) along three Mediterranean countries. Marine Pollution Bulletin, 156: 111209. https://doi.org/ 10.31230/osf.io/wudy7

Cilenti L., Pazienza G., Scirocco T., Fabbrocini A. \& D'Adamo R., 2015. First record of ovigerous Callinectes sapidus (Rathbun, 1896) in the Gargano Lagoons (south-west Adriatic Sea). BioInvasions Records, 4: 281-287. http://dx.doi.org/10.3391/bir. 2015.4.4.09

Comune di Marsala, 2015. Piano urbano della mobilità per la città di Marsala e connessa valutazione ambientale strategica. Valutazione di Incidenza Ambientale (VIncA). Allegato al Rapporto Ambientale VAS. $\mathrm{http}: / /$ www.comune.marsala.tp.it/flex/cm/pages/Serv eAttachment.php/L/IT/D/a\%252F1\%252Fb\%252FD .7aaalb8a5493ad46618e/P/BLOB\%3AID\%3D2810 3/E/pdf

Culurgioni J., Diciotti R., Satta C. T., Camedda A., de Lucia G. A., Pulina S., Lugliè A., Brundu R. \& Fois N., 2020. Distribution of the alien species Callinectes sapidus (Rathbun, 1896) in Sardinian waters (western Mediterranean). BioInvasions Record, 9(1). https:// doi.org/10.3391/bir.2020.9.1.09

Daban I.B., Cengiz O. \& Tuncer S., 2016. Further range expansion of the blue crab Callinectes sapidus (Rathbun, 1896) (Crustacea: Decapoda: Brachyura) in Turkish waters, Northern Aegean Sea: insight into distribution depth. Cahiers de Biologie Marine, 57: 175-178. https://doi.org/10.21411/CBM.A.99A19 834

Falsone F., Scannella D., Geraci M. L., Vitale S., Sardo G., \& Fiorentino F., 2020. Further records of Callinectes sapidus (Rathbun, 1896) (Decapoda, Brachyura, Portunidae) in the Strait of Sicily. Marine Biodiversity Records, 13: 1-6. https://doi.org/10. 1186/s41200-020-00190-5

Florio M., Breber P., Scirocco T., Specchiulli A., Cilenti L. \& Lumare L., 2008. Exotic species in Lesina and Varano lakes - new guest in Lesina and Varano lakes: Gargano National Park (Italy). Transitional Waters Bulletin, 2: 69-79. https://doi.org/10.1285/i1825229 Xv2n2p69

Galil B.S., 2011. The alien crustaceans in the Mediterranean Sea: an historical review. In: Galil B.S., Clark P. \& Carlton J. 2011. In the Wrong Place - Alien Marine Crustaceans: Distribution, Biology and Impacts. Invading Nature - Springer Series in Invasion Ecology, 6: 377-402.

Galil B.S., Froglia C. \& Noël P., 2002. CIESM atlas of exotic species in the Mediterranean. 2: Crustaceans: decapods and stomatopods. CIESM publishers
(Commission Internationale pour l'Exploration Scientifique de la Mer Méditerranée), Monaco, 192 pp.

Gennaio R., Scordella G. \& Pastore M., 2006. Occurrence of blue crab Callinectes sapidus (Rathbun, 1986, Crustacea, Brachyura), in the Ugento ponds area (Lecce, Italy). Thalassia salentina, 29: 29-39. https://doi.org/10.1285/115910725v29p29

Giansante C., 2012. Segnalazioni faunistiche n.119-124 (Callinectes sapidus). Quaderno di Studi e Notizie di Storia Naturale della Romagna, 36: 207-208.

Giordani Soika A., 1951. Il Neptunus pelagicus (L.) nell'alto Adriatico. Natura, 42: 18-20.

Hill J., Fowler D.L. \& Avyle M.V., 1989. Species profiles: Life histories and environmental requirements of coastal fishes and invertebrates (Mid-Atlantic) Blue crab. U.S. Army Corps of Engineers, Vicksburg, $18 \mathrm{pp}$.

Holthuis L.B. \& Gottlieb E., 1955. The occurrence of the American Blue Crab, Callinectes sapidus Rathbun, 1896, in Israel waters. Bulletin of the Research Council of Israel, section B, Zoology, 5B: 154-156. Insacco G. \& Zava B., 2017. First record of the Blue Crab Callinectes sapidus in Sicily. In: Lipej L., Acevedo I., Akel E., Anastasopoulou A., Angelidis A., Azzurro E., Castriota L., Çelik M., Cilenti L., Crocetta F., Deidun A., Dogrammatzi A., Falautano M., Fernández-Álvarez F., Gennaio R., Insacco G., Katsanevakis S., Langeneck J., Lombardo B., Mancinelli G., Mytilineou C., Papa L., Pitacco V., Pontes M., Poursanidis D., Prato E., Rizkalla S., Rodríguez-Flores P., Stamouli C., Tempesti J., Tiralongo F., Tirnetta S., Tsirintanis K., Turan C., Yaglioglu D., Zaminos G. \& Zava B., 2018. New Mediterranean Biodiversity Records (March 2017). Mediterranean Marine Science, 18, 179-201. https:// doi.org/10.12681/mms.2068

Labrune C., Amilhat E., Amoroux J. M., Jabouin C., Gigou A. \& Noël P., 2019. The arrival of the American blue crab, Callinectes sapidus Rathbun, 1896 (Decapoda: Brachyura: Portunidae), in the Gulf of Lions (Mediterranean Sea). BioInvasions Records, 8: 876-881. https://doi.org/10.3391/bir.2019.8.4.16

Mancinelli G., Carrozzo L., Costantini M. L., Rossi L., Marini G. \& Pinna M., 2013. Occurrence of the Atlantic blue crab Callinectes sapidus Rathbun, 1896 in two Mediterranean coastal habitats: Temporary visitor or permanent resident? Estuarine, Coastal and Shelf Science, 135: 46-56. https://doi.org/10.1016/j. ecss.2013.06.008

Manfrin C., Comisso G., dall'Asta A., Bettoso N. \& Sook Chung J. 2016. The return of the Blue Crab, Callinectes sapidus Rathbun, 1896, after 70 years from its first appearance in the Gulf of Trieste, northern Adriatic Sea, Italy (Decapoda: Portunidae). Check List, 12: 2006. https://doi.org/10.15560/12. 6.2006 
Mizzan L., 1993. Presence of swimming crabs of the genus Callinectes (Stimpson) (Decapoda, Portunidae) in the Venice Lagoon (North Adriatic Sea Italy): first record of Callinectes danae Smith in European waters. Bollettino del Museo civico di storia naturale di Venezia, 42: 31-43.

Pagliara P. \& Mancinelli G., 2018. Parasites affect hemocyte functionality in the hemolymph of the invasive Atlantic blue crab Callinectes sapidus from a coastal habitat of the Salento Peninsula (SE Italy). Mediterranean Marine Science, 19: 193-200. https://doi.org/ $10.12681 / \mathrm{mms} .13886$

Piras P., Esposito G. \& Meloni D., 2019. On the occurrence of the blue crab Callinectes sapidus (Rathbun, 1896) in Sardinian coastal habitats (Italy): a present threat or a future resource for the regional fishery sector? BioInvasions Records, 8: 134-141. https://doi. org/10.3391/bir.2019.8.1.15

Pipitone C., Zenone A., Badalamenti F. \& D'Anna G., 2020. First record of the blue crab Callinectes sapidus (Crustacea, Decapoda, Portunidae), a non-indigenous species in the central/southern Tyrrhenian Sea. Acta Adriatica: International journal of Marine Sciences, 61: 101-105.

Rathbun M.J. 1896. The genus Callinectes. Proceedings of the United States National Museum, 18 (1070): 349-375.

Mordenti O. \& Scaravelli D., 2007. Segnalazioni Faunistiche ${ }^{\circ} 83-87$ (Callinectes sapidus). Quaderno di Studi e Notizie di Storia Naturale della Romagna, 24: 155-160.

Sperone E., Giglio G., Abate M., Giglio S., Madeo E., Giglio A., Golia S., Sangermano I., Mauro G., Circosta V. \& Aceto M. 2015. Contribution to the knowledge of the animal xenodiversity along Calabrian coasts (southern Italy, central Mediterranean). Acta Adriatica: International journal of Marine Sciences, 56: 245-257.

Stasolla G. \& Innocenti G., 2014. New records of the invasive crabs Callinectes sapidus Rathbun, 1896 and Percnon gibbesi (H. Milne Edwards, 1853) along the Italian coasts. BioInvasions Records, 3: 39-43. http: //dx.doi.org/10.3391/bir.2014.3.1.07

Suaria G., Pierucci A., Zanello P., Fanelli E., Chiesa S. \& Azzurro E., 2017. Percnon gibbesi (H. Milne Edwards, 1853) and Callinectes sapidus (Rathbun, 1896) in the Ligurian Sea: two additional invasive species detections made in collaboration with local fishermen. BioInvasions Records, 6: 147-151. https: //doi.org/10.3391/bir.2017.6.2.10 